\title{
Diptera Brachycera found inside the esophagus of a mummified adult male from the early XIX century, Lisbon, Portugal
}

\author{
Márcia Souto Couri/ ${ }^{+}$, Sheila Maria Ferraz Mendonça de Souza' ${ }^{1}$ André Mallemont Cunha, \\ João Pinheiro², Eugénia Cunha ${ }^{3}$
}

Museu Nacional, Universidade Federal do Rio de Janeiro, Quinta da Boa Vista, 20940-040 Rio de Janeiro, RJ, Brasil 'Departamento de Endemias Samuel Pessoa, Escola Nacional de Saúde Pública Sérgio Arouca-Fiocruz, Rio de Janeiro, Brasil ${ }^{2}$ Instituto Nacional de Medicina

Legal, Delegação de Coimbra, Coimbra, Portugal ${ }^{3}$ Departamento de Antropologia, Universidade de Coimbra, Coimbra, Portugal

Fly puparia and adult fragments of diptera muscid were found inside the esophagus of a mummified body from the early XIX century, buried inside the crypt of the Sacrament Church (Lisbon, Portugal). The identification of the material revealed a monospecific colonization by Ophyra capensis (Wiedemann) (Diptera: Muscidae), a species known to invade corpses in the ammoniacal fermentation wave. This species can be found in corpses kept indoors, not available to the early waves of blowflies (Diptera: Calliphoridae). In the present case, the number of pupae and their developmental stage suggest that the female invaded the mummified corpse through the partially opened mouth and the oviposition took place directly inside the esophagus. This is the first case of $\mathrm{O}$. capensis infesting internal organs of an intact corpse. The use of chemical products for the embalming process probably explains why external colonization did not occur.

Key words: Ophyra capensis - forensic entomology - internal infestation - mummies

The collaborative project between the Paleopathology and Paleoparasitology team at Escola Nacional de Saúde Pública Sérgio Arouca-Fiocruz, the Department of Anthropology, University of Coimbra, and a forensic pathologist of the Coimbra Delegation of the Portuguese National Institute of Forensic Medicine, carried out by Sheila Maria FM Souza (SMFS), João Pinheiro (JP) and Eugênia Cunha (EC), found 72 mummified bodies in the crypt of the Church of the Sacrament in Lisbon, Portugal. Dating from the late XVIII/early XIX century, the mummies were first deposited in the crypt and later stored in a smaller sealed chamber under the altar of the church.

Like all of the corpses, the male adult herein studied (Figs 1,2) is in a good state of preservation. The clean, flexible, unshrunken skin and clean viscera and cavities point to the careful preparation of the body before the burial, probably with the use of clysters, baths, scented oils, and camphor plugs. Documentary research enabled the identification of this corpse: it belonged to João Mourão (1768-1821), a priest of the Sacrament parish, from 1804 to 1815.

During the necropsy, performed by JP, SMFS and EC, at the Department of Anthropology of Coimbra University, the larynx, the upper part of the trachea, and up-

Finnancial support: $\mathrm{CNPq}$

+ Corresponding author: mcouri@terra.com.br

Received 14 August 2007

Accepted 28 February 2008 per part of the esophagus were separated from the body to be examined and described (Fig. 3). Inside the esophagus there was an aggregate of powder and a spider web. This aggregate was removed and fragments of diptera material (11 puparia, 1 intact pupa, 1 partially destroyed male head, fragments of 6 wings and 2 legs) were found (Fig. 4). They were identified as Ophyra capensis (Wiedemann) by Márcia Souto Couri and André Mallemont Cunha and are deposited at Museu Nacional, Brazil.

This is originally an old world species, known to have a wide distribution in the world. In Europe, it is the commonest species of Ophyra in the Mediterranean countries, including Portugal, becoming scarcer northwards (Skidmore 1985). It breeds in numerous media and is known to invade corpses after other flies, such as Muscina Robineau-Desvoidy (Muscidae) and Calliphora Robineau-Desvoidy (Calliphoridae), but before the phorids (Phoridae). Sometimes it is found on human bodies kept indoors for several months, where blowflies (Diptera, Calliphoridae) do not have access to them (eg., Smith 1986, Bourel et al. 2004).

According to Skidmore (1985) the biology of $O$. capensis is very like that of Ophyra ignava, also a native Ophyra of the old world and another important muscoid species with forensic importance. Three annual emergences were observed in Britain for O. ignava, in June, August and October. Graham-Smith (1916 in Skidmore 1985 ) found that the flies began to emerge from the ground in spring when mean soil temperatures below the surface reached about $14^{\circ} \mathrm{C}$. In South Yorkshire, the life cycle of $O$. ignava was accomplished in about 4-6 weeks (Skidmore 1985). This provides a model to suppose the time period and conditions of this mummy infestation.

Lefebvre and Pasquerault (2004) studied the influence of rearing temperature on the development rates 


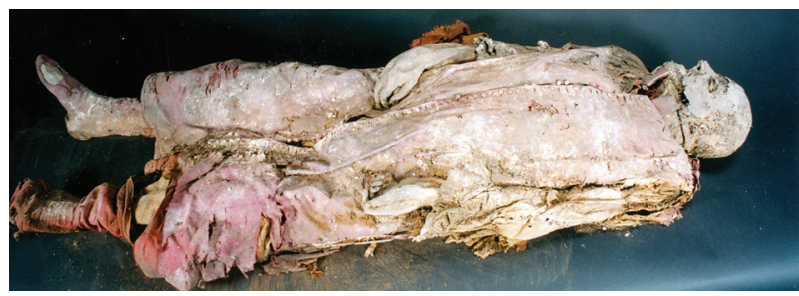

Fig. 1: mummified body of a man of the early 19th century, found in the Church of the Sacrament, Lisbon, before necropsy.

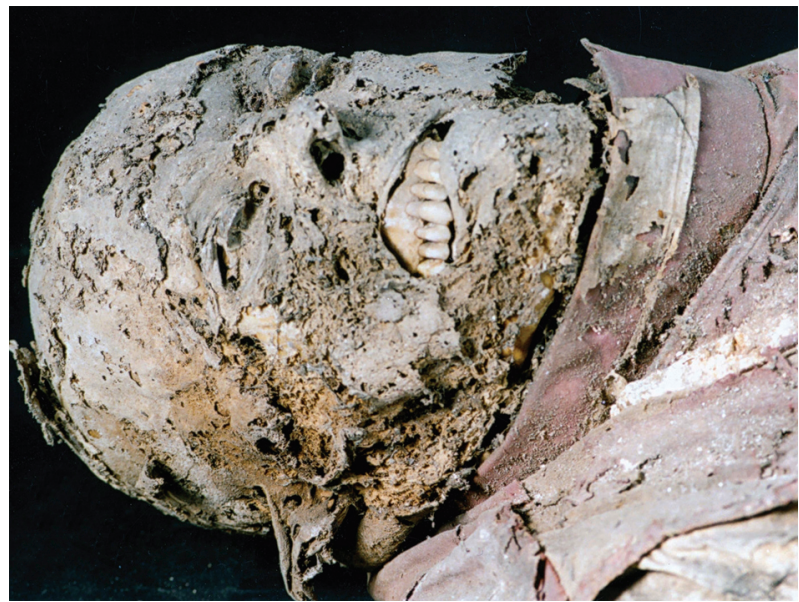

Fig. 2: mummified body of a man of the early 19th century found in the Church of the Sacrament, Lisbon. Detail of the head.

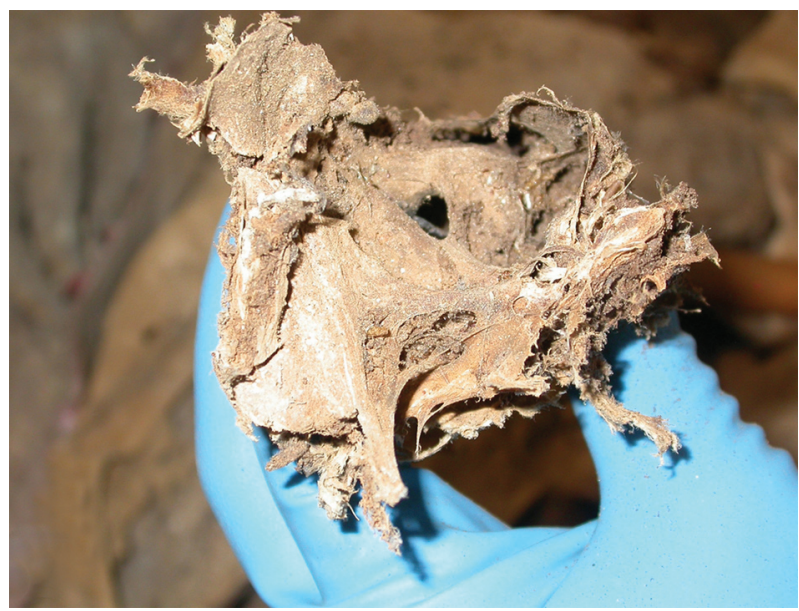

Fig. 3: detail of the dissected esophagus of the mummy with the pupae and other dipteran fragments.

of Ophyra aenescens and $O$. capensis. Replications, at a relative moisture of $75-95 \%$, were run at $17^{\circ} \mathrm{C}, 24^{\circ} \mathrm{C}$, and $30^{\circ} \mathrm{C}$, and the average minimum time periods for total development of $O$. capensis were, respectively, 62, 21.1 and 12.5 days.

As is known, insect development is greatly influenced by many environmental conditions, and temperature is the most significant factor. Ribeiro et al. (2001) studied the complete cycle (egg-larvae-pupa) of $O$. aene-

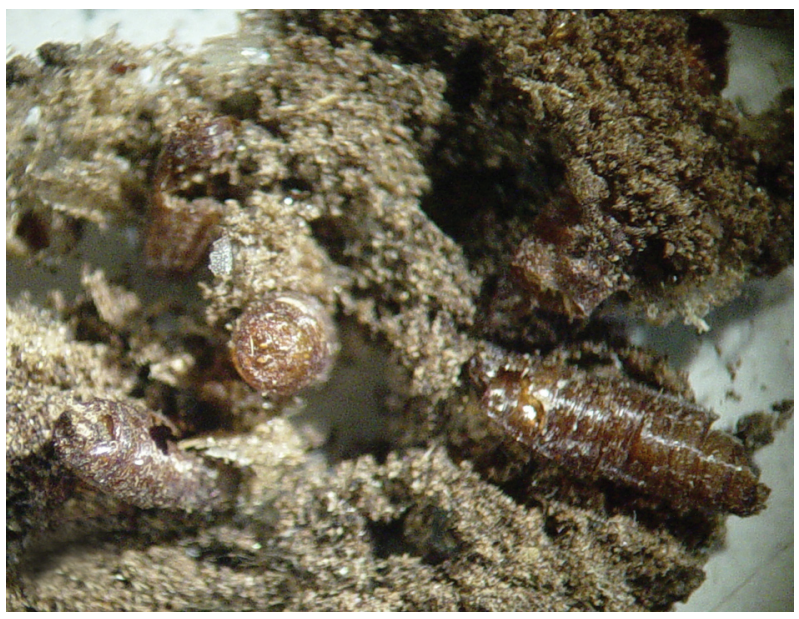

Fig. 4: material collected inside the esophagus of the mummy.

scens in a laboratory and found that the viability varied from $38.86 \%$ at $15^{\circ} \mathrm{C}$ to $75.97 \%$ at $30^{\circ} \mathrm{C}$, with the larvae the most susceptible stage. Ribeiro et al. (2000) tested the viability of $O$. aenescens at $5,10,15,20,25,30,35$ and $40^{\circ} \mathrm{C}$ with $\mathrm{RH}$ above $80 \%$. The life cycle was completed at temperatures between 10 to $35^{\circ} \mathrm{C}$, with lower viabilities at $15^{\circ} \mathrm{C}$ and $10^{\circ} \mathrm{C}$ but none at 5 or $40^{\circ} \mathrm{C}$.

Because taphonomic processes may have destroyed some of the puparia and insects, we cannot be sure if the small number recovered represents the total number of insects inside the esophagus. If the small number of puparia does represent all of the viable larvae, this low number is probably explained by the low temperatures inside the crypt.

Many species of Diptera: Brachycera, among other insects, are known to infest dead humans and according to their biology, life cycle, and preferences for laying eggs, among other behavioral aspects, they supply information in legal death investigations. The faunal succession of the species in dead bodies is mostly used for estimating the postmortem interval. Dipterous larvae, in particular, are very useful, because they breed in specific places, and more importantly, they stay there. Their surrounding environment determines their development, and their study provides extremely detailed information about location, time and manner of death (Passagiotakopulu 2004). Ophyra species have a specific forensic significance, appearing usually during the period of amoniacal fermentation.

The number of waves of insects in the succession on carrion has been differently interpreted by different authors (Smith 1986) and the associated fauna will be different depending on whether the corpses are exposed, buried in soil, or immersed in water. If the body has not been exposed to the open air but kept indoors in dry conditions, protected from the early waves of blowflies, it may show maggots and pupae of Ophyra after a period of several months.

Ophyra species have been reported in literature from buried corpses (Mégnin 1894 in Smith 1986) and other 
forensic evaluations of crime histories with monospecific populations (Turchetto \& Vanin 2004, as Hydrotaea capensis, Bourel et al. 2004, Grassberger \& ScharrerLiška 2006).

Perhaps the excellent conditions of preservation of the insects in the Lisbon mummy is also related to the preparation of the corpse, probably with arsenic or some other product (toxicology study has not been finished yet) which could also have retarded bacterial activity. From the end of the 18th to the 19th centuries, the injection of an arseniac solution into the veins helped to preserve bodies in many places where people could pay for it (Aufderheide 2003), and such embalming practices were possibly in use in Lisbon at this time among the social elite. In this mummy, the preservation of the external tissues, including the skin, in contrast with the poor preservation of the lungs, heart, spleen, liver and other organs, suggests that only the resistant fibrous structures inside the body were able to survive the fermentation phase. On the other hand, the skin is very well preserved, as are the thoracic and abdominal walls, so the outside of the body would possibly have been less attractive to the flies.

According to the position and number of the insects, the oviposition was probably directly into the esophagus of the mummy, possibly through the partially opened mouth (Fig. 2). The female fly sought internal, incompletely mummified tissues to lay her eggs. The preservation suggests that the mummy was kept indoors, inside the crypt, and thus probably avoided the first wave of infestation by blowflies. The infestation may have occurred several months (but probably less than one year) after the deposition, during the slow fermentation phase following the mummification.

The present case is noteworthy because it is the first record instance of $O$. capensis invading internal human organs in a mummified body.

\section{REFERENCES}

Aufderheide AC 2003. The scientific study of mummified human remains, Cambridge University Press, Cambridge, 608 pp.

Bourel B, Tournel G, Hédouin V, Gosset D 2004. Entomofauna of buried bodies in northern France. Int J Legal Med 118: 215-220.

Grassberger M, Scharrer-Liška G 2006. Archaeoentomology: examination and interpretation of entomological specimens from a 1200year-old burial site in Austria. EAFE, European Association for Forensic Entomology. Abstracts, Fourth Meeting. Available from: http://new.eafe.org/bari_fichiers/Poster/Grassberger_Bari.jpg.

Lefebvre F, Pasquerault T 2004. Temperature-dependent development of Ophyra aenescens (Wiedemann, 1830) and Ophyra capensis (Wiedemann, 1818) (Diptera Muscidae). Forensic Sci Int 139: 75-79.

Passagiotakopulu E 2004. Dipterous remains and archaeological interpretation. J Archaeol Sci 31: 1675-1684.

Ribeiro PB, Carvalho CJB, Costa PRP, Silveira P Jr 2000. Desenvolvimento de Ophyra aenescens Wiedemann, 1830 (Diptera, Muscidae, Azeliinae), em diferentes temperaturas, em condições de laboratório. Rev Bras Agroc 6: 80-87.

Ribeiro PB, Carvalho CJB, Regis M, Costa PRP 2001. Exigências térmicas e estimativa do número de gerações de Ophyra aenescens Wiedemann, 1830 (Diptera, Muscidae, Azeliinae), em Pelotas, RS. Arq Inst Biol 68: 75-82.

Santana F, Sucena E 1994. Dicionário da História de Lisboa, Carlos Quintas e Associados Consultores, Lisboa, 211 pp.

Savage J, Wheeler TA 2004. Phylogeny of the Azeliini (Diptera: Muscidae). Stud Dipterol 11: 259-299.

Skidmore P 1985. The biology of the Muscidae of the world. Series Entomologica 29: 1-550.

Smith, KGV 1986. A Manual of Forensic Entomology, The Trustees of the British Museum (Natural History), London, 205 pp.

Turchetto M, Vanin S 2004. Forensic evaluations on a crime case with monospecific necrophagous fly population infeceted by two parasitoid species. Aggrawal's Internet J Forensic Med Toxicol 5: 12-18. 